\author{
MARIUSZ KOTULSKI \\ ORCID: 0000-0002-4957-2363 \\ Uniwersytet Jagielloński \\ mariusz.kotulski@uj.edu.pl
}

\title{
Instytucje wzmacniające korporacyjny charakter gminy
}

\begin{abstract}
Abstrakt: Instytucje prawne umożliwiają mieszkańcom gminy — członkom wspólnoty samorządowej — aktywny udział w sprawowaniu władzy, kontrolowanie jej, a także współdecydowanie o części budżetu. Zwiększają poczucie partycypacji i współodpowiedzialności za decyzje podejmowane przez członków korporacji. Korporacyjne podejście do gminy tworzy upodmiotowienie tej samorządowej wspólnoty pod względem prawnym, socjologicznym i aksjologicznym.
\end{abstract}

Słowa kluczowe: korporacja, gmina, samorząd, wybory, referendum, konsultacje społeczne, budżet partycypacyjny, inicjatywa uchwałodawcza, jednostki pomocnicze gminy.

\section{Korporacja jako rudymentarny element gminy}

\section{Jak słusznie wskazywał Tadeusz Bigo:}

jeśli panuje zgoda co do tego, że samorząd jest formą administracji publicznej, to samorząd możemy łączyć tylko z osobami zbiorowemi, grupami. Jako predykację możemy słowo: „samozarządzać” odnieść nie do każdego podmiotu, lecz do grup społecznych, podmiotów zbiorowych, bo wyobrażenie administracji publicznej drogą koniecznej asocjacji łączymy zawsze ze zbiorowością, grupą a nie jednostką izolowaną. [...] Tylko o grupach społecznych korporacyjnie zorganizowanych możemy powiedzieć, że same zarządzają, bo na mocy norm organizacyjnych one same (członkowie) ustanawiają organa, sprawujące administrację bezpośrednio ${ }^{1}$.

Ujęcie to było akceptowane w doktrynie już w okresie przedwojennym. Na rozstrzygającą cechę samorządu uwzględniającego w swojej organizacji „w naj-

1 T. Bigo, Związi publiczno-prawne w świetle ustawodawstwa polskiego, Warszawa 1928, s. $150-151$. 
szerszej mierze czynnik obywatelski, powołując go do decydowania o sprawach publicznych" wskazywał między innymi Maurycy Jaroszyński ${ }^{2}$. W swoich rozważaniach podnosił on, że samorząd „o tyle ma rację bytu i spełnia swoje przeznaczenie, o ile w nim »czynnik obywatelski« rzeczywiście decyduje, czyli, o ile zbliża nas do ideału, w myśl którego praktyczna działalność samorządu pokrywa się z wyrazem woli danej społeczności"3. Należy zatem dążyć do tego, aby praktyczna działalność danej jednostki samorządowej odpowiadała „woli zbiorowej” tworzącej ją korporacji przynajmniej w zasadniczych kwestiach i ogólnych ramach.

Władztwo sprawowane przez mieszkańców to według Bigi essentiale związku. Z chwilą utraty przymiotu władztwa, tak jak i w przypadku braku mieszkańców, związek publicznoprawny przestaje istnieć. Władztwo przejawi się w formie przymusu tworzenia i przymusu członkostwa. Tak jak decentralizacja, zdaniem Bigi, stanowi kryterium rozróżnienia organów samorządowych od organów rządowych, tak korporacyjność wyodrębnia samorząd spośród innych typów decentralizacji ${ }^{4}$. Jak pisał: „tylko przy korporacji możemy mówić o samodzielności zarządu w szerszym zasięgu, bo nie tylko w znaczeniu uchylenia podporządkowania hierarchicznego, ale także w sensie autonomicznej organizacji”.

Również po „przywróceniu” w 1990 roku gminy jako jednostki samorządu terytorialnego wskazywano w doktrynie na korporacyjny charakter samorządu terytorialnego jako na niezbędny element tego pojęcia 6 .

Już w Europejskiej Karcie Samorządu Lokalnego przyjętej przez Radę Europy w Strasburgu 15 października 1985 roku$^{7}$ podkreślony został element korporacji, a w konsekwencji jej rudymentarne prawo do decydowania o własnych sprawach. W art. 3 Karty samorząd terytorialny ujęty został jako prawo i rzeczywista zdolność społeczności lokalnych; w granicach określonych ustawą, do regulowania i zarządzania — na ich wyłączną odpowiedzialność i w interesie ich mieszkańców - zasadniczą częścią spraw publicznych. Owo prawo jest realizowane w sposób pośredni przez rady i zgromadzenia oraz bezpośrednio, na przykład poprzez referendum. To społeczności lokalne mają pełną swobodę działania w każdej dziedzinie, która nie jest wyłączona z ich kompetencji. Kompetencje przyznane społecznościom lokalnym są w zasadzie całkowite i nienaruszalne, a one same powinny być konsultowane zawsze, gdy jest to możliwe, szczególnie w przypadku opracowywania planów oraz podejmowania decyzji w kwestiach

${ }^{2}$ M. Jaroszyński, Rozważania ideologiczne i programowe na temat samorzadu, Warszawa 1936, s. 8 .

3 Ibidem, s. 12.

4 T. Bigo, Zwiazki..., s. 82 n.

5 T. Bigo, Prawo administracyjne. Instytucje ogólne, Wrocław 1948, s. 76.

6 Zob. np. J. Szreniawski, Prawo administracyjne - część ogólna, Lublin 1994 s. 130; E. Ochendowski, Prawo administracyjne - część ogólna, Toruń 1996, s. 207; A. Agopszowicz, Z. Gilowska, Ustawa o samorzadzie terytorialnym. Komentarz, Warszawa 1997, s. 47; M. Kulesza, Niektóre zagadnienia prawne definicji samorządu terytorialnego, „Państwo i Prawo”, 1990, nr 1 s. 22.

7 Dz.U. z 1994 r. Nr 124, poz. 607. 
bezpośrednio ich dotyczących (art. 4 Karty). Każda modyfikacja granic terytorialnych społeczności lokalnej wymaga uprzedniego przeprowadzenia konsultacji w tej społeczności, także w drodze referendum (art. 5 Karty). W preambule do Europejskiej Karty Samorządu Terytorialnego podniesiono między innymi, iż społeczności lokalne stanowią jedną z zasadniczych podstaw ustroju demokratycznego; prawo obywateli do uczestniczenia w zarządzaniu sprawami publicznymi wchodzi do zakresu demokratycznych zasad wspólnych dla wszystkich państw członkowskich Rady Europy, a prawo to właśnie na szczeblu lokalnym może być realizowane w sposób najbardziej bezpośredni i stwarza warunki do zarządzania w bezpośredniej bliskości obywatela.

Powszechnie więc uznaje się, iż zapewnienie udziału społeczeństwa w administracji publicznej przez powierzenie samorządnym korporacjom części administracji i obowiązku zaspokajania jej niektórych potrzeb jest bardziej efektywne i opłacalne. Zatem samorząd terytorialny tak w ujęciu doktrynalnym, jak i w praktyce funkcjonowania poszczególnych jego jednostek należy postrzegać i analizować w kontekście przyznanego mu władztwa publicznoprawnego oraz korporacyjnego charakteru. Nie sposób bowiem wyobrazić sobie istnienie jakiegokolwiek samorządu (w tym oczywiście terytorialnego) bez elementu korporacji, która stanowi istotny substrat tego pojęcia ${ }^{8}$. Tym samym czynnik ludzki jest niewątpliwie istotną cechą samorządu terytorialnego, gdyż zasadza się na korporacyjności powołanego przez państwo związku publicznoprawnego9 .

W ustawie o samorządzie gminnym wprost wskazuje się, że to mieszkańcy gminy tworzą z mocy prawa wspólnotę samorządową, a ta wraz z odpowiednim terytorium kreuje gminę ${ }^{10}$. Od czasu przywrócenia gminy samorządowej w Polsce ustawodawca stopniowo wprowadzał szereg regulacji wzmacniających jej korporacyjny charakter. Także idea społeczeństwa obywatelskiego (coraz chętniej i szerzej podejmowana przez świadomych swoich praw oraz odpowiedzialności za dobro wspólne członków korporacji tworzących wspólnotę samorządową) sprzyja szerzeniu się różnych form partycypacji politycznej i społecznej w sprawowaniu władzy, czy też w realizacji zadań (budżety obywatelskie, grupy inicjatyw lokalnych, młodzieżowe rady gmin, gminne rady seniorów itp.).

Instytucje, które wzmacniają korporacyjny substrat gminy, mogą mieć charakter: ustrojowy, organizacyjny, kontrolny, finansowo-majątkowy, albo mieszany. Mogą one odnosić się także do wszystkich mieszkańców gminy albo być kierowane tylko do wyodrębnionej wedle określonego kryterium części korporacji.

8 „Podmiotowość samorządową przyznaje się ludności danego terenu, a nie temu terenowi, należy jednostkę samorządu terytorialnego ujmować wyłącznie w aspekcie podmiotowym" B. Dolnicki, Organizacja i funkcjonowanie administracji terenowej, Katowice 1989, s. 151.

${ }^{9}$ Zob. M. Kotulski, Pojęcie i istota samorządu terytorialnego, „Samorząd Terytorialny” 2000, nr 1-2, s. 89.

10 Art. 1 ustawy z dnia 8 marca 1990 roku o samorządzie gminnym (tekst jedn. Dz.U. z 2020 r. poz.713, dalej: u.s.g.). 


\section{Wybory i system przedstawicielski}

Podstawowym czynnikiem spajającym wspólnotę samorządową na szczeblu gminy jest sprawowanie przez nią władzy. Władza należy do mieszkańców gminy, którzy sprawują ją bezpośrednio lub pośrednio (art. 11 ust. 1 u.s.g.). W codziennym funkcjonowaniu gminy jest ona sprawowana pośrednio poprzez organy: stanowiący (radę gminy) i wykonawczy (wójta, burmistrza, prezydenta miasta). Istotne w przypadku gminy jest to, że oba organy, co do zasady, pochodzą z wyborów bezpośrednich. Niewątpliwie wzmacnia to ich legitymację do sprawowania władzy (zwłaszcza w przypadku organu wykonawczego, gdyż czyni go w tym aspekcie podmiotem równoważnym radzie gminy, inaczej niż ma to miejsce na szczeblu powiatu lub województwa samorządowego). To z właśnie z organami gminy ustawodawca wiąże szereg zadań i kompetencji, z których część ma charakter wyłączny. Zatem wybory są podstawową instytucją spajającą i aktywizującą wspólnotę samorządową, umożliwiającą jej sprawowanie władzy (w sposób pośredni) poprzez wybór osób sprawujących funkcje organów gminy, a także dokonanie przy akcie wyboru oceny pracy radnych oraz organu wykonawczego w poprzedniej kadencji, jeżeli ubiegają się o reelekcję.

\section{Referendum gminne}

Obok wyborów instytucją wzmacniającą korporacyjny charakter gminy jest referendum gminne. Może mieć ono charakter ustrojowy (referendum jako element bezpośredniego sprawowania władzy — przeprowadzane w każdej istotnej dla gminy sprawie - art. 2 ust. 1 pkt 2 i 3 ustawy z dnia 15 września 2000 roku o referendum lokalnym ${ }^{11}$ czy też $\mathrm{w}$ sprawie utworzenia, połączenia, podziału i zniesienia gminy oraz ustalenia jej granic — art. 4c u.s.g.), bezpośredniej kontroli (referendum w sprawie odwołania organu gminy przed upływem kadencji — art. 2 ust. 1 pkt 1 oraz ust. 2 pkt 1 u.r.l.), a nawet majątkowy i finansowy (na przykład referendum w sprawie samoopodatkowania - art. 2 ust. 2 pkt u.r.1.), Jednocześnie instytucja referendum w najszerszym zakresie i najpełniej realizuje koncepcję bezpośredniego działania korporacji tworzącej gminę. Możliwość wypowiedzenia się w drodze referendum uzupełnia, wzbogaca, a czasami nawet modyfikuje system przedstawicielski. Różnorodne formy demokracji bezpośredniej (zwłaszcza referendum) oraz pośredniej (systemu przedstawicielskiego) powinny być wzajemnie komplementarne. Zakres i proporcje stosowania form demokracji pośredniej i bezpośredniej uzależnione są od szczebla zarządzania: im niższy szczebel, tym większe możliwości stosowania instytucji demokracji bezpośred-

11 Tekst jedn. Dz.U. z 2019 r. poz. 741, dalej: u.r.1. 
niej. Na szczeblu lokalnym instytucja referendum znajduje najbardziej dogodne warunki do urzeczywistnienia ${ }^{12}$. Referendum lokalne w ujęciu materialnym zostało określone przez ustawodawcę jako wyrażenie przez członków wspólnoty samorządowej w drodze głosowania swojej woli co do sposobu rozstrzygnięcia sprawy dotyczącej tej wspólnoty. Zatem istota referendum zawiera się w powszechnym i bezpośrednim udziale uprawnionych obywateli, z których każdy dysponuje jednym głosem, a decydujące znaczenie ma wola większości ${ }^{13}$.

Mieszkańcy — członkowie wspólnoty samorządowej, podejmując rozstrzygnięcia w drodze referendum, „wchodzą" w kompetencje organów danej jednostki samorządu terytorialnego, przejmują ich kompetencje do rozstrzygania sprawy do podjęcia decyzji. Pogląd, że przedmiotem referendum nie mogą być sprawy należące do właściwości innych organów, byłby zaprzeczeniem istoty instytucji referendum ukształtowanej na gruncie prawa polskiego i stanowiłby, w świetle treści art. 2 ustawy o referendum, przejaw wykładni contra legem ${ }^{14}$.

Należy pamiętać, że takie referendum zostaje ograniczone w świetle art. 169 ust. 1 Konstytucji RP, gdyż mieszkańcy w drodze referendum nie mogą zastępować organów jednostek samorządu terytorialnego, którym powierzona została wyłączna kompetencja. Dopuszczalne jest jednak referendum o skutku abrogacyjnym, „które będzie zobowiązywać właściwy organ stanowiący do uchylenia podjętego uprzednio rozstrzygnięcia" ${ }^{15}$. Szczególnie mobilizujące i integrujące gminną korporację są referenda (także fakultatywne, lecz zwłaszcza obligatoryjne) przeprowadzane z inicjatywy mieszkańców. Wynika to z wymogów związanych z przeprowadzeniem takiego referendum: konieczności uzyskania poparcia pozostałych mieszkańców dla idei przeprowadzenia referendum, przeprowadzenia kampanii referendalnej, wreszcie osiągnięcia odpowiedniej frekwencji w głosowaniu, aby referendum było ważne, oraz poparcia dla konkretnego rozwiązania w sprawie poddanej pod referendum, aby wynik był rozstrzygający (art. 4, 5, 11, 14, 28, 55, 56 u.r.l.). Przykładowo referendum konsultacyjne jest świetnym probierzem nastrojów i preferencji danej wspólnoty samorządowej i stanowi swego rodzaju instrument korelujący porozumiewanie się pomiędzy korporacją kreującą

12 E. Olejniczak-Szałowska, Referendum lokalne w świetle ustawodawstwa polskiego, Warszawa 2002, s. 29.

13 Zob. E. Zieliński, Referendum w świecie współczesnym, Wrocław-Warszawa-Kraków 1968, s. 5.

14 Szerzej zob. E. Olejniczak-Szałowska, op. cit., s.135 oraz wyrok Trybunału Konstytucyjnego z dnia 26 lutego 2003 roku (sygn. K 30/02, OTK-A 2003, nr 2, poz.16), stwierdzający zgodność przepisu art. 2 ust. 1 ustawy z dnia 15 września 2000 roku o referendum lokalnym z Konstytucją. W przywołanym wyroku Trybunał Konstytucyjny orzekł o zgodności art. 2 ust. 1 u.r.l., rozumianego jako niewyłączający prawa członków wspólnoty samorządowej do wyrażania w drodze referendum stanowiska w istotnych sprawach dotyczących społecznych, gospodarczych lub kulturowych więzi łączących tę wspólnotę, a niezastrzeżonych do wyłącznej kompetencji organów innych władz publicznych — z art. 2 i 170 Konstytucji RP oraz z art. 5 Europejskiej Karty Samorządu Terytorialnego.

15 Zob. wyrok WSA w Krakowie z dnia 26 września 2013 roku, sygn. III SA/Kr 899/13, LEX nr 1371548 oraz M. Kotulski, Referendum lokalne, „Ruch Prawniczy, Ekonomiczny i Socjologiczny" 2017, z. 3, s. 109-118. 
gminę a organami tejże gminy. Oczywiście nie ma ono charakteru rozstrzygającego i wiążącego, ale zawiera stanowisko wspólnoty samorządowej, które w ten sposób wyrażone wzmacnia lub osłabia (albo wręcz jej pozbawia) legitymizację organów gminy do podjęcia określonego rozwiązania, inicjatywy, działania itp. w sprawie będącej przedmiotem referendum. Wydaje się, że wraz z upowszechnianiem się postaw i ruchów obywatelskich, znaczenie referendum lokalnego jako najistotniejszej z form demokracji bezpośredniej będzie nadal wzrastać, aż stanie się ono uzupełniającym (ale nie wykluczającym) elementem sprawowania władzy przez mieszkańców. „Jest ono bowiem istotną, wręcz pierwotną formą partycypacji członków we wspólnocie samorządowej, polegającą na uczestniczeniu w jej zarządzaniu poprzez akt wyboru"16.

\section{Konsultacje społeczne}

Kolejna instytucja to konsultacje z mieszkańcami gminy (art. 5a u.s.g.) w sprawach ważnych dla gminy, a także w sprawach zmiany granic gmin lub granic miasta polegającej na wyłączeniu obszaru lub części obszaru jednostki pomocniczej gminy i jego włączeniu do sąsiedniej jednostki pomocniczej tej gminy lub do sąsiedniej gminy (art. 4a ust. 1 i 2, art. 4 b ust. 1 u.s.g.). Wprawdzie konsultacje z mieszkańcami gminy, podobnie jak referendum gminne, mogą być obligatoryjne (na przykład w zakresie zmiany granic gminy) lub fakultatywne (w każdej innej ważnej sprawie — na podstawie prawa miejscowego, którym będzie uchwała rady gminy w sprawie zasad i trybu przeprowadzenia konsultacji ${ }^{17}$ ), to jednak co do zasady nie mają one wiążącego charakteru. O ile konsultacje nie dają mieszkańcom gminy bezpośredniego wpływu na decyzje (te nadal są ostatecznie zarezerwowane dla organów gminy), o tyle są czymś więcej niż tylko „zwykłym” informowaniem przez organy gminy członków wspólnoty samorządowej o planowanych działaniach lub jedynie sondażem co do preferencji mieszkańców. Celem takich konsultacji jest uzyskanie opinii, poznanie stanowiska, czy też preferencji mieszkańców co do przedstawianych przez organy gminy problemów, propozycji działań itp. dotyczących tego związku publicznoprawnego, a tym samym — bez-

16 M. Kotulski, Referendum..., s. 118.

17 Dopuszczalne jest przyjęcie zarówno uchwały „ogólnej”, na podstawie której mogą być prowadzone konsultacje społeczne w różnych sprawach, jak również uchwały „,problemowej”, która ma zastosowanie do konkretnej sprawy. W każdym wypadku taka uchwała jest powszechnie obowiązującym prawem miejscowym (wyrok NSA z dnia 29 maja 2015 roku, sygn. II GSK 942/14, LEX nr 1982688). „W uchwale podejmowanej na podstawie art. 5a ust. 2 u.s.g. rada gminy powinna określić między innymi: kto inicjuje konsultację, sposób i formę konsultacji, czas i miejsce ich przeprowadzenia, reguły ustalania wyników oraz sposób przekazania tych wyników do wiadomości społeczności lokalnej” - wyrok WSA we Wrocławiu z 10 maja 2013 roku, sygn. III SA/Wr 140/13, LEX nr 1330077. 
pośrednio lub pośrednio — samych mieszkańców. W swej istocie zakładają więc komunikację pomiędzy organami gminy a tworzącymi ją członkami korporacji poprzez obostronny przepływ informacji. „Konsultacje są formą dialogu mieszkańców i NGO z władzami Miasta, wpływają na zaangażowanie mieszkańców w jego rozwój, kształtują wśród mieszkańców postawę współodpowiedzialności za podejmowane decyzje, budują współpracę międzysektorową pomiędzy NGO a Miastem oraz zapewniają mieszkańcom uczestnictwo w procesie podejmowania rozstrzygnięć bezpośrednio wpływających na sposób i jakość ich życia. Celem konsultacji społecznych jest polepszanie jakości współpracy mieszkańców oraz rozwój współpracy NGO z władzami Miasta. Informowanie na wczesnym etapie prac o planowanych przedsięwzięciach i ich efektach oraz zbieranie opinii i propozycji do wykorzystania przy podejmowaniu decyzji dotyczących tych przedsięwzięć, wzmacnianie kapitału społecznego poprzez rozwijanie idei społeczeństwa obywatelskiego" ${ }^{18}$. Zatem konsultacje są postrzegane jako dialog pomiędzy organami gminy a jej mieszkańcami, podczas którego zbierane są poglądy mieszkańców w poddanym konsultacjom przedmiocie, a na ich podstawie podejmowane są przez te organy optymalne decyzje z zakresu administracji publicznej. Co ważne i zarazem wzmacniające w tym procesie upodmiotowienia korporacji, konsultacje nie ograniczają się wyłącznie do przedstawienia i opiniowania gotowych już propozycji, na przykład aktów prawnych (ich zmiany lub uchwalania nowych), inwestycji lub innych przedsięwzięć, które będą miały wpływ na życie i pracę mieszkańców, ale także mogą dotyczyć wypracowywania przyszłych rozwiązań lub diagnozowania potrzeby $\mathrm{w}$ obszarze, $\mathrm{w}$ którym $\mathrm{w}$ przyszłości podejmowane będą decyzje publiczne. Niewątpliwie odwołanie się do szerszej analizy społecznej i poszukiwanie rozwiązań dla przedmiotu konsultacji pomaga organom gminy podejmować decyzje przy poszanowaniu zasady dobra wspólnego. Są zatem konsultacje społeczne jedną z form partycypacji obywatelskiej, czyli włączania mieszkańców gminy w proces podejmowania decyzji dotyczących spraw publicznych. O tym, które sprawy są ,ważne”, decydują w zasadzie organy gminy. Jedynym ograniczeniem jest to, aby ich zakres mieścił się w ramach zadań powierzonych przez ustawodawcę gminie. Przy wskazywaniu podmiotów uprawnionych do inicjowania procesu konsultacji, z uwagi na ich istotę, celowe jest przyznanie takiej inicjatywy szerokiemu kręgowi podmiotów: nie tylko organom gminy, ale także mieszkańcom ${ }^{19}$, organizacjom społecznym, przedsiębiorcom, itp. Tym samym

18 Paragraf 2 ust. 1 i 2 uchwały nr CXI/2904/18 Rady Miasta Krakowa z dnia 26 września 2018 roku w sprawie zasad i trybu przeprowadzania konsultacji z mieszkańcami Gminy Miejskiej Kraków oraz z Krakowską Radą Działalności Pożytku Publicznego lub organizacjami pozarządowymi i podmiotami, o których mowa w art. 3 ust. 3 ustawy z dnia 24 kwietnia 2003 roku o działalności pożytku publicznego i o wolontariacie projektów aktów prawa miejscowego w dziedzinach dotyczących działalności statutowej tych organizacji.

19 Sam zakres znaczeniowy kategorii „mieszkaniec” gminy rodzi jednak pewne problemy interpretacyjne. Zgodnie z przepisami prawa cywilnego, będzie nim osoba fizyczna, która przebywa 
obok rady gminy i wójta (burmistrza, prezydenta miasta) z wnioskiem o przeprowadzenie konsultacji mogą również wystąpić sami mieszkańcy (struktury organizacyjne skupiające lub reprezentujące mieszkańców). O tym, jak dużą grupę muszą stanowić, by zawnioskować o przeprowadzenie konsultacji, decyduje rada gminy $^{20}$. Natomiast o tym, czy przeprowadzić wnioskowane z inicjatywy mieszkańców konsultacje, decyduje organ gminy (najczęściej organ wykonawczy, gdyż to na nim spoczywa realizacja tego zadania).

\section{Budżet obywatelski}

Jak wskazuje sam prawodawca, szczególną formą konsultacji społecznych jest budżet obywatelski (art. 5a ust. 3 u.s.g.). Podkreślić jednak należy, że w przypadku budżetu obywatelskiego mieszkańcy mają ,mocniejszą pozycję” niż w przypadku „typowych” konsultacji (stają się bowiem rzeczywistym partnerem organów gminy), gdyż to oni decydują o wyborze zadania lub zadań, na jakie mają zostać przeznaczone tak wyodrębnione środki finansowe gminy. Budżet obywatelski nazywany jest często budżetem partycypacyjnym ${ }^{21}$, gdyż mieszkańcy mogą aktywnie współuczestniczyć w kreacji istotnych dla nich celów w ramach zadań publicznych gminy (tak na szczeblu ogólnogminnym, jak i na poziomie jednostek pomocniczych) oraz realnie współdecydować o przeznaczeniu części środków budżetu gminy ${ }^{22}$. Szczególnie widoczne jest to w przypadku gmin bę-

w danym miejscu i posiada wolę stałego tam przebywania. W orzecznictwie wskazuje się, że nie jest dopuszczalne ustanawiania wymogu, od którego spełnienia zależne jest prawo do uczestnictwa w konsultacjach, w postaci figurowania w odpowiedniej ewidencji, na przykład rejestrze wyborczym lub zameldowania na pobyt stały lub czasowy na terenie danej gminy (wyrok WSA w Gliwicach z dnia 14 stycznia 2014 roku, sygn. I SA/Gl 1291/13, LEX nr 1529502). Podobnie nie jest dopuszczalne wprowadzanie kryteriów opartych na wieku lub zamieszkiwania w danej części gminy, na przykład na terenie sołectwa, którego sprawy podlegają zaopiniowaniu w procesie konsultacji. Zatem takie szerokie ujmowanie pojęcia „mieszkaniec gminy” umożliwia uczestnictwo w konsultacjach społecznych każdej osobie fizycznej, a gmina nie ma podstaw prawnych do weryfikowania takiego przymiotu, stąd praktyczną podstawą do uznania za „mieszkańca” będzie jedynie stosowne oświadczenie osoby zainteresowanej.

${ }^{20}$ W Krakowie na podstawie $\S 5$ pkt 3 cyt. wyżej uchwały z dnia 26 września 2018 roku z wnioskiem o przeprowadzenie konsultacji wystąpić mogą: a) grupa co najmniej 300 mieszkańców, b) Rada Dzielnicy Miasta Krakowa, c) grupa co najmniej 8 NGO, d) Krakowska Rady Działalności Pożytku Publicznego, e) Rada Krakowskich Seniorów, f) komisja lub zespół zadaniowy Rady, g) Młodzieżowa Rada Miasta Krakowa, h) Komisja Dialogu Obywatelskiego, i) Powiatowa Społecznej Rady ds. Osób Niepełnosprawnych.

21 Szerzej zob. D. Fleszer, Budżet obywatelski - oczekiwania, realia, [w:] Partycypacja spoŁeczna we współczesnym samorzadzie terytorialnym, red. M. Gurdek, Sosnowiec 2016.

22 „Instytucja budżetu obywatelskiego została wprowadzona do u.s.g. w celu zwiększenia udziału obywateli w procesie wybierania, funkcjonowania i kontrolowania niektórych organów publicznych. Budżet obywatelski służy angażowaniu mieszkańców w proces podejmowania decyzji, 
dących miastami na prawach powiatu, gdzie utworzenie budżetu obywatelskiego jest obowiązkowe, a jego wysokość wynosi co najmniej $0,5 \%$ wydatków gminy zawartych w ostatnim sprawozdaniu z wykonania budżetu (art. 5a ust. 5 u.s.g.). $\mathrm{W}$ ramach budżetu obywatelskiego mieszkańcy podczas konsultacji, ale $\mathrm{w}$ formie bezpośredniego głosowania, rozstrzygają corocznie część wydatków budżetu gminy. Zadania wybrane w ramach budżetu obywatelskiego zostają następnie uwzględnione w uchwale budżetowej gminy, a sama rada gminy w toku prac nad projektem uchwały budżetowej nie może usuwać lub zmieniać w stopniu istotnym zadań wybranych w ramach budżetu obywatelskiego (art. 5 a ust. 4 u.s.g.). Równie ważne jest to, że środki wydatkowane w ramach budżetu obywatelskiego mogą być dzielone na pule obejmujące zarówno całość gminy, jak i jej części w postaci jednostek pomocniczych lub ich grup (art. 5 ust. 6 u.s.g.). Taka możliwość podziału środków aktywizuje mieszkańców, a przez to wzmacnia więzi wewnątrzkorporacyjne także na poziomie jednostek pomocniczych gminy. Wymogi formalne projektów i tryb przeprowadzenia głosowania nad budżetem obywatelskim określa rada gminy (art. 5a ust. 7 u.s.g.). Powinna ona w sposób maksymalnie szeroki umożliwiać mieszkańcom zgłaszanie projektów do budżetu obywatelskiego (sam ustawodawca ogranicza wymagany stopień poparcia zgłaszanego projektu do nie więcej niż $0,1 \%$ mieszkańców terenu objętego pulą budżetu obywatelskiego, na którym zgłaszany jest dany projekt) ${ }^{23}$.

\section{Obywatelska inicjatywa uchwałodawcza oraz skarga na uchwały i zarządzenia organów gminy}

Biorąc pod uwagę zjawisko odwróconej hierarchii źródeł prawa powszechnie obowiązującego, w praktyce funkcjonowania organów gminy, a przez to także dla jej mieszkańców, szczególne znaczenie ma prawo miejscowe, gdyż wpływa ono w sposób istotny na kształtowanie ich sytuacji prawnej. Ustawodawca, uwzględniając lokalną specyfikę, powierzył między innymi gminie stanowienie przepisów prawa lokalnego. Wprawdzie prawo miejscowe jest stanowione przez radę gminy

które zadania publiczne w określonym roku budżetowym powinny zostać zrealizowane, a co za tym idzie - sfinansowane ze środków publicznych. Decydentami w powyższym zakresie nie mogą być zatem osoby nie będące mieszkańcami gminy" - wyrok WSA w Rzeszowie z dnia 5 lutego 2019 roku, sygn. II SA/Rz 1185/18, LEX nr 263465.

${ }^{23}$ W uchwale nr XXXV/903/20 z dnia12 lutego 2020 roku w sprawie Regulaminu budżetu obywatelskiego Miasta Krakowa podziału środków dokonano w proporcji $80 \%$ na zadania o charakterze dzielnicowym i 20\% na zadania o charakterze ogólnomiejskim. Z projektem o charakterze dzielnicowym i ogólnomiejskim może wystąpić każdy mieszkaniec miasta, a w terminie siedmiu dni od dnia złożenia projektu ma on dołączyć listę poparcia dla zgłoszonego projektu podpisaną przez co najmniej 15 mieszkańców miasta. 
(ewentualnie organ wykonawczy w przypadku przepisów porządkowych), lecz ze znaczną możliwością bezpośredniego wpływania członków wspólnoty samorządowej na kształt i zakres obowiązujących w gminie przepisów. Pomijając powołane wyżej referendum o skutku abrogacyjnym, szczególne znaczenie w tym zakresie mają dwie instytucje: obywatelska inicjatywa uchwałodawcza oraz skarga na uchwały i zarządzenia organów gminy.

Inicjatywę uchwałodawczą możemy zaliczyć do przejawów demokracji bezpośredniej sprawowanej przez mieszkańców gminy. „Uprawnienie to jest więc instrumentem służącym uwalnianiu energii społecznej mieszkańców danej jednostki samorządu terytorialnego, które ma na celu podniesienie autorytetu i wzrost akceptowalności tworzonego prawa. Ponadto stanowi skuteczne narzędzie ułatwiające szybką i adekwatną reakcję prawną na zmieniającą się rzeczywistość"24. Niewątpliwie jest to także przejaw wyrazu woli lokalnego suwerena, który poprzez podjęta inicjatywę, dąży do bezpośredniego wpływu na kształtowanie prawa miejscowego obowiązującego na terenie gminy. Jeszcze przed wprowadzeniem art. 41a u.s.g. ${ }^{25}$ Naczelny Sąd Administracyjny wskazał, że uprawnienie do przyznania inicjatywy uchwałodawczej grupie mieszkańców należy wiązać z podmiotowym aspektem definicji wspólnoty samorządowej, zawartej w art. 1 ust. 1 u.s.g., zgodnie z którym wspólnotę samorządową tworzą mieszkańcy gminy. „Wobec tego podmiotem terytorialnie zrzeszonej wspólnoty jest społeczność zamieszkała na danym obszarze [...] Zdaniem Naczelnego Sądu Administracyjnego ten korporacyjny charakter samorządu pozwala na przyznanie inicjatywy uchwałodawczej tworzącej go społeczności"26. Takie poszerzenie kręgu podmiotów inicjujących proces uchwałodawczy ma doniosłe znaczenie dla demokratyzacji procesu prawotwórczego, a zwłaszcza udziału mieszkańców w decyzjach

24 P.B. Zientarski, E. Mreńca, Obywatelska inicjatywna uchwałodawcza w procesie stanowienia aktów prawa miejscowego, Warszawa 2018, s. 5.

25 Nowelą z dnia 11 stycznia 2018 roku o zmianie niektórych ustaw w celu zwiększenia udziału obywateli w procesie wybierania, funkcjonowania i kontrolowania niektórych organów publicznych (Dz.U. z 2018 r. poz. 130). W uzasadnieniu do projektu tej ustawy wskazano, że proponowane zmiany w ustawach samorządowych ,realnie przyczynią się do zapewnienia społeczności lokalnej większego udziału w funkcjonowaniu organów danej jednostki samorządu terytorialnego, pochodzącej z aktu wyboru oraz zagwarantują obywatelom właściwą kontrolę nad władzą samorządową, a tym samym przyczynią się do zwiększenia więzi oraz odpowiedzialności za wspólnotę samorządową, w której zamieszkują [...]. Projekt wprowadza instytucję obywatelskiej inicjatywy ustawodawczej. Będzie ona przysługiwała odpowiednio grupie mieszkańców gminy, powiatu, województwa. Ustawa określa liczbę osób, mających prawo wystąpić z powyższą inicjatywą. Projekty ustaw zgłoszone w ramach obywatelskiej inicjatywy uchwałodawczej będą musiały stać się przedmiotem obrad najbliższej sesji organu stanowiącego odbywającej się nie później niż po upływie trzech miesięcy od daty złożenia projektu. Komitet inicjatywy uchwałodawczej będzie miał prawo wskazać osoby, które będą uprawnione do reprezentowania komitetu podczas prac nad projektem uchwały" — druk sejmowy VIII.2001.

26 Wyrok NSA z dnia 21 listopada 2013 roku, sygn. II OSK 1887/13, ONSAiWSA 2015, nr 3, poz. 52 . 
publicznych oraz wpływu obywateli na działalność organów państwowych i samorządowych ${ }^{27}$. Wprowadzając obywatelską inicjatywą uchwałodawczą ustawodawca wskazał, że grupa mieszkańców gminy, posiadających czynne prawa wyborcze do organu stanowiącego, która może wystąpić z obywatelską inicjatywą uchwałodawczą musi, w zależności od liczby mieszkańców gminy, liczyć co najmniej100, 200 lub 300 osób (odpowiednio w gminach do 5 tysięcy, 20 tysięcy i powyżej 20 tysięcy mieszkańców). Natomiast szczegółowe zasady wnoszenia inicjatyw obywatelskich, zasady tworzenia komitetów inicjatyw uchwałodawczych, zasady promocji obywatelskich inicjatyw uchwałodawczych, formalne wymogi, jakim muszą odpowiadać składane projekty, z zastrzeżeniem przepisów u.s.g., stanowi w drodze uchwały rada gminy. Jak wyjaśnił Naczelny Sąd Administracyjny (NSA), zasadami „wnoszenia inicjatyw obywatelskich”, a także „tworzenia komitetów obywatelskich" w rozumieniu delegacji ustawowej z art. 41a ust. 5 u.s.g., jest zbiór podstawowych reguł postępowania dla wnoszenia inicjatyw obywatelskich, a także tworzenia komitetów obywatelskich ${ }^{28}$. Realizacja obywatelskiej inicjatywy uchwałodawczej wymaga szeregu czynności po stronie zarówno obywateli, jak i organów gminy, wynikających z treści art. 41a ust. 1-5 u.s.g. NSA wyróżnił w ramach tych przepisów dwa etapy działań dla realizacji obywatelskiej inicjatywy uchwałodawczej. W ramach pierwszego, organizacyjno-formalnego, następuje utworzenie komitetu, który podejmuje czynności związane z przygotowaniem projektu uchwały, kampanią promocyjną i organizacją zbierania podpisów mieszkańców posiadających czynne prawa wyborcze do organu stanowiącego. Podczas pierwszego etapu następuje też weryfikacja projektu uchwały pod względem formalnym, w szczególności w zakresie wymaganej liczby poparcia i kończy się on skierowaniem projektu pod obrady rady. Drugi etap, który można nazwać merytorycznym, dotyczy rozpatrywania projektu przez radę, a więc właściwego procedowania nad nim. Ta materia wykracza poza granice art. $41 \mathrm{a}$ ust. 5 u.s.g. Natomiast czynności podejmowane przez organy gminy w ramach pierwszego etapu organizacyjno-formalnego mieszczą się w granicach „zasad wnoszenia inicjatyw obywatelskich" 29 . Dodać należy, że aktualnie brakuje podstaw prawnych rangi ustawowej do limitowania czasu, w jakim można zbierać podpisy pod projektem uchwały. W istocie bowiem ograniczanie czasu zbierania podpisów realnie uszczupla mieszkańcom gminy, posiadającym czynne prawo wyborcze do organu stanowiącego, możliwość skorzystania z obywatelskiej inicjatywy uchwałodawczej. Inicjatywa uchwałodawcza może więc być ważnym instrumentem w rękach świadomych i aktywnych mieszkańców w ich działaniach na rzecz korporacji.

27 Zob. K. Działocha, Udział czynnika społecznego w procesie tworzenia prawa, „Przegląd Prawa i Administracji” 18, 1985, s. 7-28.

28 Wyrok z dnia 22 listopada 2019 roku, sygn. I OSK 1410/19, LEX nr 2778120.

29 Por. wyrok WSA w Poznaniu z dnia 22 stycznia 2020 roku, sygn. IV SA/Po 763/19, LEX nr 2780407. 
W swoistej korelacji do stanowienia prawa miejscowego pozostaje instytucja skargi wnoszonej w trybie art. 101 u.s.g., która umożliwia uruchomienie kontroli sądowej podjętych przez organy gminy uchwał lub zarządzeń z zakresu administracji publicznej. Skargę na taką uchwałę lub zarządzenie można wnieść do sądu administracyjnego w imieniu własnym lub reprezentując grupę mieszkańców gminy, którzy wyrażą na to pisemną zgodę. Jest to niewątpliwie instytucja, która wraz z innymi - zasadą jawności działania organów gminy, dostępem do informacji publicznej oraz raportem o stanie gminy — stanowi instrument umożliwiający i wzmacniający kontrolę korporacji nad działalnością organów gminy.

\section{Zasada jawności działalności organów gminy i dostęp do informacji publicznych}

Jawność działalności organów gminy obejmuje w szczególności prawo obywateli do uzyskiwania informacji, wstępu na sesje rady gminy i posiedzenia jej komisji, a także dostęp do dokumentów wynikających z wykonywania zadań publicznych, w tym protokołów posiedzeń organów gminy i komisji rady gminy (art. 11b u.s.g.), a także obowiązek transmitowania i utrwalania za pomocą urządzeń rejestrujących obraz i dźwięk z obrad gminy ${ }^{30}$ (art. 20 ust. 1b u.s.g.). Również gospodarka finansowa gminy jest jawna, a wójt ma obowiązek informować mieszkańców gminy o założeniach projektu budżetu, kierunkach polityki społecznej i gospodarczej oraz wykorzystywaniu środków budżetowych (art. 61 ust. 1 i 3 u.s.g.).

Skoro przepisy u.s.g. nie wyłączają stosowania ustawy z 6 września 2001 roku o dostępie do informacji publicznej ${ }^{31}$, to również ona może służyć uzyskaniu informacji o działalności organów gminy. Zgodnie z art. 61 ust. 1 Konstytucji RP, „prawo do uzyskiwania informacji” to prawo do informacji o „działalności organów władzy publicznej oraz osób pełniących funkcje publiczne”, a także „innych osób oraz jednostek organizacyjnych w zakresie, w jakim wykonują one zadania władzy publicznej i gospodarują mieniem komunalnym". Z kolei art. 61 ust. 2 Konstytucji RP wskazuje, że ,prawo do uzyskiwania informacji obejmuje dostęp do dokumentów oraz wstęp na posiedzenia kolegialnych organów władzy publicznej pochodzących z powszechnych wyborów, z możliwością rejestracji dźwięku lub obrazu". Wprawdzie posiedzenia kolegialnych organów władzy publicznej pochodzących z powszechnych wyborów są jawne i dostępne (art. 18 u.d.i.p.), jednak organy te „sporządzają i udostępniają protokoły lub stenogramy swoich obrad, chyba że sporządzą i udostępnią materiały audiowizualne lub teleinformatyczne rejestrujące w pełni te obrady” (art. 19 u.d.i.p.). Pojęcie ,informacji

30 Same nagrania obrad są udostępniane w Biuletynie Informacji Publicznej i na stronie internetowej gminy oraz w inny sposób zwyczajowo przyjęty.

31 Tekst jedn. Dz. U. z 2018 r. poz. 1330 ze zm., dalej jako: u.d.i.p. 
publicznej" ustawodawca określił w przepisach art. 1 ust. 1 i art. 6 u.d.i.p., wskazując, że informacją taką jest każda informacja o sprawach publicznych. Sprawami publicznymi są sprawy związane z istnieniem i funkcjonowaniem określonej wspólnoty publicznoprawnej. Określenie sprawy jako „publicznej” wskazuje, że jest to sprawa ogółu i koresponduje w znacznym stopniu z pojęciem dobra wspólnego (dobra ogółu). Takie rozumienie pojęcia „sprawa publiczna” związane jest $\mathrm{z}$ władzą publiczną i wspólnotą publicznoprawną oraz jej funkcjonowaniem ${ }^{32}$.

\section{Debata nad raportem o stanie gminy}

Podobne cele - informacyjne i kontrolne - realizuje przedstawienie przez wójta (burmistrza, prezydenta miasta) raportu o stanie gminy, który obejmuje podsumowanie działalności wójta w roku poprzednim, w szczególności realizację polityk, programów i strategii, uchwał rady gminy i budżetu obywatelskiego (art. 28aa ust. 1-3 u.s.g.). Co istotne, w debacie nad raportem o stanie gminy mogą zabierać głos nie tylko radni, ale również mieszkańcy gminy, którzy złożyli przewodniczącemu rady pisemne zgłoszenie poparte podpisami: w gminie do 20 tysięcy mieszkańców — co najmniej 20 osób a w gminie powyżej 20 tysięcy mieszkańców - co najmniej 50 osób (art. 28 aa ust. 6 i 7 u.s.g.).

Umożliwienie mieszkańcom jednostki samorządu terytorialnego wzięcia udziału w debacie nad raportem o stanie tej jednostki i zabierania w niej głosu ocenić należy jako wyraz umacniania społeczeństwa obywatelskiego w samorządzie [...]. Stanowi to daleko idącą formę zaangażowania mieszkańców w dokonywaną ocenę działalności organu wykonawczego. Można jednak się zastanawiać, czy głos mieszkańców w każdej sytuacji będzie miał charakter obiektywny i oparty będzie na rzetelnych, rzeczowych zarzutach odnoszących się do działalności organu wykonawczego, a nie na przykład na przymiotach osobistych jego samego lub jego członków czy przekonaniach politycznych ${ }^{33}$.

\section{Młodzieżowa rada gminy oraz gminna rada seniorów}

Instytucjami o charakterze organizacyjnym są młodzieżowa rada gminy oraz gminna rada seniorów (art. 5b i 5c u.s.g.). Co istotne, obie rady stanowią przykład instytucji kierowanych do określonej wedle kryterium wieku części korpo-

32 Zob. H. Izdebski, Samorzad terytorialny. Podstawy ustroju i działalności, Warszawa 2004, s. 209; wyroki NSA z dnia 30 września 2009 roku, sygn. I OSK 2093/14, LEX nr 1839074 oraz z dnia 9 lutego 2021 roku, sygn. III OSK 2946/21, LEX nr 3151398.

33 W. Baranowska-Zając, Instytucje społeczeństwa obywatelskiego w świetle nowelizacji samorzadowych ustaw ustrojowych z 11 stycznia 2018 r., "Studia Prawnoustrojowe UMW" 2019, nr 44, s. 13.

Prawo 333, 2021

(C) for this edition by CNS 
racji tworzącej gminę. Obie rady są tworzone przez radę gminy, która w ten sposób wspiera i upowszechnia ideę samorządową wśród młodzieży lub sprzyjając solidarności międzypokoleniowej, tworzy warunki do pobudzania aktywności obywatelskiej osób starszych w społeczności lokalnej. O ile młodzieżowa rada młodzieżowa ma charakter jedynie konsultacyjny ${ }^{34}$, o tyle gminna rada seniorów poszerza charakterystykę o funkcje doradczą i inicjatywną. W przypadku powołania zarówno młodzieżowej rady gminy, jak i gminnej rady seniorów lokalny prawodawca umożliwia tym grupom społecznym zaangażowanie w sprawy dla nich istotne oraz udziału w procesie uchwałodawczym, chociaż ogranicza się on do wyrażenia niewiążących opinii ${ }^{35}$.

\section{Programy inicjatyw lokalnych}

W ujęciu organizacyjnym wspomnieć należy także o kreowanych w gminach programach inicjatyw lokalnych, które umożliwiają mieszkańcom gminy, organizacjom pozarządowym (NGO), jednostkom pomocniczym zgłaszanie wniosków o realizację zadania publicznego. Inicjatywa lokalna jest formą współpracy gminy z jej mieszkańcami, w celu wspólnego realizowania zadania publicznego na rzecz społeczności gminy. Podejmowanie inicjatyw lokalnych służy realizacji przedsięwzięć zmierzających do zaspokajania zbiorowych potrzeb oraz przyczynia się do poprawy warunków życia i aktywizacji społeczności lokalnej.

\section{Jednostki pomocnicze gminy}

Niewątpliwie również tworzenie przez rady gminy jednostek pomocniczych gminy prowadzi do wzmocnienia wyodrębnionych tym razem terytorialnie części korporacji gminy. Wprawdzie utworzenie jednostki pomocniczej przez radę gminy jest fakultatywne, rada gminy czyni to po przeprowadzeniu konsultacji z mieszkańcami lub z ich inicjatywy. Istotą wyodrębnienia takich części jest realizowanie zadań gminy w ramach wewnętrznej dekoncentracji, na niższym po-

34 Owo zasięganie konsultacji młodzieżowej rady gminy może dotyczyć na przykład edukacji publicznej, kultury, sportu, miejsc rekreacji, urządzeń sportowych, w sprawach związanych z rozwojem młodego pokolenia, organizowaniem imprez czy spotkań propagujących ideę samorządową. Zob. T. Moll, Młodzieżowe rady gmin, „Wspólnota” 2005, nr 15, s. 39 oraz idem, Rada seniorów - sposób realizacji potrzeby zwiększania aktywności społecznej osób starszych, „Samorząd Terytorialny" 2015, nr 11, s. 66-76.

35 Istotne obawy dotyczące rad seniorów, tak od strony podmiotowej, jak i organizacyjnej sformułował M. Mączyński, [w:] Ustawa o samorządzie gminnym. Komentarz, red. P. Chmielnicki, Warszawa 2013, s. 142-144. 
ziomie w maksymalnym przybliżeniu do mieszkańców, co należy odczytywać jako wyraz zasady subsydiarności. Jest to szczególnie istotne w dużych gminach miejskich ${ }^{36}$. Jednocześnie w małych gminach (przede wszystkim wiejskich) występujące w ramach korporacji danej jednostki pomocniczej więzi (społeczne, kulturowe, gospodarcze, zawodowe, ekonomiczne, religijne, czy też związane z identyfikacją lokalną) są dużo liczniejsze i silniejsze. Dodatkowo wspomnieć należy, że w przypadku sołectwa (i wyjątkowo osiedla) udział mieszkańców w sprawowaniu władzy przybiera formę demokracji bezpośredniej poprzez zebranie wiejskie (zebranie osiedla), które jest organem uchwałodawczym. Pomimo że jednostki pomocnicze zostały wyposażone we własne organy, a ich organy wykonawcze mogą uczestniczyć (bez prawa głosu) w obradach rady gminy, wydaje się, że potencjał tej instytucji nie został jeszcze w pełni wykorzystany ${ }^{37}$. Ich rola bowiem, w zależności od treści statusu, ogranicza się zazwyczaj do funkcji opiniodawczej aspektu konsultacyjnego i wykonywania zadań w ramach przekazanych im środków budżetowych oraz zarządzania i korzystania $\mathrm{z}$ mienia komunalnego (w tym także rozporządzania dochodami z tego źródła w zakresie określonym w statucie).

W kontekście dysponowania mieniem wspólnym szczególną rolę ustawodawca przypisał sołectwom. Otóż rada gminy nie może uszczuplić dotychczasowych praw sołectw do korzystania z mienia bez zgody zebrania wiejskiego, a wszystkie przysługujące dotychczas mieszkańcom wsi prawa własności, użytkowania lub inne prawa rzeczowe i majątkowe pozostają nienaruszone (art. 48 ust. 2 i 3 u.s.g.). Oznacza to, że zgoda mieszkańców wsi jest warunkiem koniecznym do uszczuplenia zakresu korzystania z mienia, a jej brak stanowi o nieważności uchwały rady gminy ${ }^{38}$. W skład zebrania wiejskiego wchodzą wszyscy mieszkańcy stanowiący społeczność wiejską i prawo do samodzielnego wyrażania zgody na zadysponowanie składnikiem majątkowym, o której mowa w art. 48 ust. 2 u.s.g. przysługuje tej społeczności jako podmiotowi. Jak wskazuje Kazimierz Bandarzewski:

ustawodawca zastrzegł na rzecz organu sołectwa prawo do samodzielnego wyrażania zgody na zadysponowanie składnikiem majątkowym. Uprawnienie to ma charakter prawnokształtujący. Podmiotem tego prawa jednak może być, i jest, dana społeczność (społeczność wiejska) i prawo to przysługuje właśnie takiej społeczności jako podmiotowi [...]. W ujęciu cywilnoprawnym, zebranie wiejskie, o którym stanowi art. 48 ust. 2 u.s.g., to nic innego jak społeczność lokalna. Pod takim właśnie „szyldem” zebranie to powinno wyrażać zgodę — nie jako jednostka pomocnicza, ale jako mieszkańcy wsi ${ }^{39}$.

36 Dotyczy to również Warszawy, choć tu powołanie dzielnic przez radę m. st. Warszawy jest obligatoryjne, a ich nazwy, zakres działania i gospodarka finansowe zostały określne ustawowo art. 5 i nast. ustawy z 15 marca 2002 roku o ustroju miasta stołecznego Warszawy, tekst jedn. Dz.U. 2018 r. poz. 1817.

37 Zob. K. Ważny, Czy potrzebny jest nowy model ustrojowy jednostek pomocniczych w gminach miejskich, „Gdańskie Studia Prawnicze” 34, 2015, s. 89 n.

38 Zob. wyrok NSA z 10 stycznia 1995 roku, sygn. SA/Wr 411/94, LEX nr 964293.

39 K. Bandarzewski, [w:] Ustawa o samorzadzie gminnym. Komentarz, red. P. Chmielnicki, Warszawa 2013, s. 694-695. 
Należy również wspomnieć o możliwości wyodrębnienia przez radę gminy w ramach budżetu środków stanowiących tak zwany fundusz sołecki ${ }^{40}$. Środki z funduszu sołeckiego przeznaczone są na realizację przedsięwzięć będących zadaniami własnymi gminy, służących poprawie warunków życia mieszkańców i zgodnych ze strategią rozwoju gminy ${ }^{41}$. Przedsięwzięcia te powinny zostać zgłoszone we wniosku sołectwa, który uchwala zebranie wiejskie z inicjatywy sołtysa, rady sołeckiej lub co najmniej 15 pełnoletnich mieszkańców sołectwa.

\section{Podsumowanie}

Wskazane instytucje prawne, umożliwiające mieszkańcom gminy — członkom wspólnoty samorządowej — aktywne uczestnictwo w sprawowaniu władzy na tym poziomie, często w sposób bezpośredni (referendum lokalne, konsultacje, zebranie wiejskie), a także współdecydowanie o części budżetu (budżet obywatelski, fundusz sołecki), niewątpliwie wzmacniają identyfikację korporacji ze „swoją" gminą. Skoro władza należy do mieszkańców gminy ${ }^{42}$, to mają oni prawo do realnego, szerokiego, a przede wszystkim opartego na partnerstwie i wzajemnym szacunku uczestnictwa w sprawowaniu nad nią władzy poprzez prawem przewidziane instytucje. Te pozwalają także na podnoszenie poziomu społecznego zaufania do lokalnych władz (konsultacje) poprzez transparentność podejmowanych działań (zasada jawności, dostęp do informacji publicznej). Jednocześnie zwiększa to wśród członków korporacji poczucie współuczestnictwa, a także współodpowiedzialności za podejmowane decyzje. Już Perykles w mowie ku czci bohaterów poległych w pierwszym roku wojny peloponeskiej stwierdził, że obywatel niebiorący czynnego udziału w życiu polis jest jednostką nie bierną, lecz nieużyteczną ${ }^{43}$. Tym samym korporacyjne ujęcie gminy kreuje upodmiotowienie tej wspólnoty samorządowej tak w aspekcie prawnym, socjologicznym, jak i aksjologicznym. Natomiast pozostaje otwartą kwestia, czy i w jakim zakresie człon-

40 „Tym samym uznać należy uprawnienie zebrania wiejskiego jako organu uchwałodawczego sołectwa za przejaw udziału społeczności lokalnej (w tym przypadku tylko mieszkańców danego sołectwa) w procedurze uchwalania budżetu" - M. Agustyniak, Budżet partycypacyjny jako instrument uczestnictwa mieszkańców w sprawowaniu władzy na poziomie lokalnym - wnioski i postulaty, [w:] Zastosowanie idei public governance $w$ prawie administracyjnym, red. I. Niżnik-Skrzydło, Warszawa 2014, s. 125.

41 Zob. ustawa z 21 lutego 2014 roku o funduszu sołeckim, Dz.U. z 2014 r. poz. 301.

42 Także w kontekście idei good governance, w której społeczeństwo powinno być źródłem wszelkiej władzy politycznej. W konsekwencji w koncepcji tej można upatrywać elementów tego, co określa się jako „demokrację uczestniczącą”, „demokrację partnerską”, „demokrację interaktywną". Zob. H. Izdebski, Samorząd terytorialny Podstawy ustroju i działalności, Warszawa 2011, s. 43.

${ }^{43}$ Za R. Piekarski, Lokalna wspólnota polityczna a zagadnienie tożsamości zbiorowej, Kraków 2001, s. 57. 
kowie wspólnoty samorządowej tworzący gminę fakt ten sobie uświadamiają oraz na ile konstruktywnie i skutecznie, dla dobra wspólnego, potrafią korzystać z przysługujących im przejawów upodmiotowionego współuczestnictwa w sprawowaniu władztwa przez gminną wspólnotę samorządową.

\section{Bibliografia}

Agopszowicz A., Gilowska Z., Ustawa o samorzadzie terytorialnym. Komentarz, Warszawa 1997.

Agustyniak M., Budżet partycypacyjny jako instrument uczestnictwa mieszkańców w sprawowaniu władzy na poziomie lokalnym - wnioski i postulaty, [w:] Zastosowanie idei public governance w prawie administracyjnym, red. I. Niżnik-Skrzydło, Warszawa 2014.

Bandarzewski K., [w:] Ustawa o samorzadzie gminnym. Komentarz, red. P. Chmielnicki, Warszawa 2013.

Baranowska-Zając W., Instytucje społeczeństwa obywatelskiego w świetle nowelizacji samorządowych ustaw ustrojowych z 11 stycznia 2018 r., „Studia Prawnoustrojowe UMW” 2019, nr 44.

Bigo T., Prawo administracyjne. Instytucje ogólne, Wrocław 1948.

Bigo T., Związki publiczno-prawne w świetle ustawodawstwa polskiego, Warszawa 1928.

Dolnicki B., Organizacja i funkcjonowanie administracji terenowej, Katowice 1989.

Działocha K., Udziat czynnika społecznego w procesie tworzenia prawa, „Przegląd Prawa i Administracji” 18, 1985.

Fleszer D., Budżet obywatelski - oczekiwania, realia, [w:] Partycypacja społeczna we współczesnym samorzadzie terytorialnym, red. M. Gurdek, Sosnowiec 2016.

Izdebski H., Samorząd terytorialny. Podstawy ustroju i działalności, Warszawa 2004.

Jaroszyński M., Rozważania ideologiczne i programowe na temat samorzadu, Warszawa 1936.

Kotulski M., Pojęcie i istota samorządu terytorialnego, „Samorząd Terytorialny”, 2000, nr 1-2.

Kotulski M., Referendum lokalne, „Ruch Prawniczy, Ekonomiczny i Socjologiczny” 2017, z. 3.

Kulesza M., Niektóre zagadnienia prawne definicji samorządu terytorialnego, „Państwo i Prawo” 1990, nr 1 .

Mączyński M., [w:] Ustawa o samorządzie gminnym. Komentarz, red. P. Chmielnicki, Warszawa 2013.

Moll T., Młodzieżowe rady gmin, „Wspólnota” 2005, nr 15.

Moll T., Rada seniorów - sposób realizacji potrzeby zwiększania aktywności społecznej osób starszych, „Samorząd Terytorialny” 2015, nr 11.

Ochendowski E., Prawo administracyjne - część ogólna, Torun 1996.

Olejniczak-Szałowska E., Referendum lokalne w świetle ustawodawstwa polskiego, Warszawa 2002.

Piekarski R., Lokalna wspólnota polityczna a zagadnienie tożsamości zbiorowej, Kraków 2001.

Ważny K., Czy potrzebny jest nowy model ustrojowy jednostek pomocniczych w gminach miejskich, „Gdańskie Studia Prawnicze” 34, 2015.

Szreniawski J., Prawo administracyjne - część ogólna, Lublin 1994.

Zieliński E., Referendum w świecie wspótczesnym, Wrocław-Warszawa-Kraków 1968.

Zientarski P.B., Mreńca E., Obywatelska inicjatywna uchwałodawcza w procesie stanowienia aktów prawa miejscowego, Warszawa 2018. 


\title{
Institutions Strengthening the Corporate Character of the Commune
}

\begin{abstract}
Summary
Legal institutions enable the residents of the commune - members of the self-government community - to actively participate in exercising power, control it, as well as co-decide about part of the budget. They increase the sense of participation and shared responsibility for the decisions made by the members of the corporation. The corporate approach to the commune creates empowerment of this self-government community in legal, sociological, and axiological terms.
\end{abstract}

Keywords: corporation, commune, local government, elections, referendum, public consultation, participatory budget, resolution initiative, auxiliary units of the commune. 